\title{
Boron deficiency in cacao, bananas and other crops on volcanic soils of Ecuador
}

\author{
D. TOLLENAAR \\ Bilthoven, The Netherlands
}

\section{Summary}

Detailed evidence is given, that boron deficiency affects imported cacao varieties in Ecuador, which are destroyed at the beginning of their productive stage. The local varieties usually survive, but B-deficiency affects their production and makes them susceptible to such diseases as Marasmius (WB) and Ceratocystis. The first evidence is given that bananas in the field are affected by B-deficiency. On young volcanic terraces of the Riverine Belt their leaf canopy and fruit quality are affected. B-deficiency in cacao and bananas has so far not been reported from any other country. A general survey proved that also affected on young volcanic soils are arabica and robusta coffee, avocado pear, mango, chinese cabbage, alfalfa, trefoil, potato, sweet clover and apple. Its occurrence is apparently of a general and persistent kind and is promoted by the prevailing soil and climatic conditions. Research on practical control methods is a suitable object of international aid.

\section{Cacao}

\subsection{Introduction}

Since 1957 large new cacao areas in Ecuador have been planted with Trinitario-Scavina hybrids developed in Trinidad, where they had been found to show a high tolerance to witches' broom (WB) and hybrid growth vigour, and to give extremely high yields (BARTLEY, 1957).

These cacao families also developed well in Ecuador during the first years of their life. In the first year they grew a jorquette and soon the first fruit appeared. In their third year, however, the turning point was marked by profuse flowering and several other abnormalities (e.g. excessive chupon formation, leaf curling). There was no fruitset and from then on the plantation rapidly decayed. "Flushing" and leaf-shedding became too frequent, and they were followed by die-back of branches, swelling, cracking and gumming of the main trunk and branches, and in the final stage by severe WB (to which they were previously tolerant), Ceratocystis and other diseases. In one or two years' time the once healthy plantations were destroyed (Fig. 1). Large areas of these hybrids planted subsequent to 1957 have been lost in this way.

The sterility phenomenon (profuse flowering without fruit-set) was the first indication of B-deficiency, as this element is essential for fertilization and as there was no other reason for the sterility. Extensive field and cytological research in Trinidad had shown that pollination within these families ensures an abundant fruit-set (COPE, 1958). But despite flowering and the presence of midges that were often seen visiting the flowers, fruit-set failed.

Received for publication: September 5, 1965. 


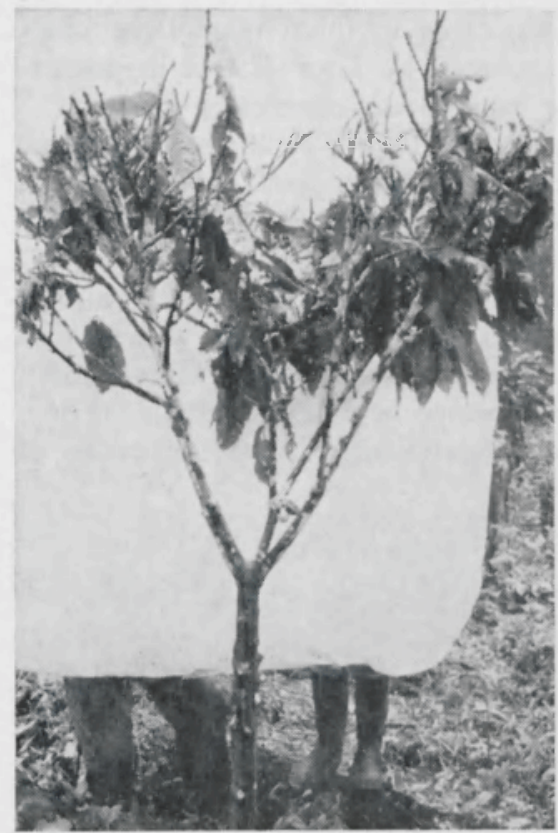

Fig. 1. Final stage of B-deficiency; broom-like branching (no WB). One parthenocarpic fruit. Note many wounds from cut chupons on trunk and branches. The frame shows that the beginning was normal.

Fig. 2. A healthy-looking, 21/2-year old cacao plant suddenly develops B deficient shoot.
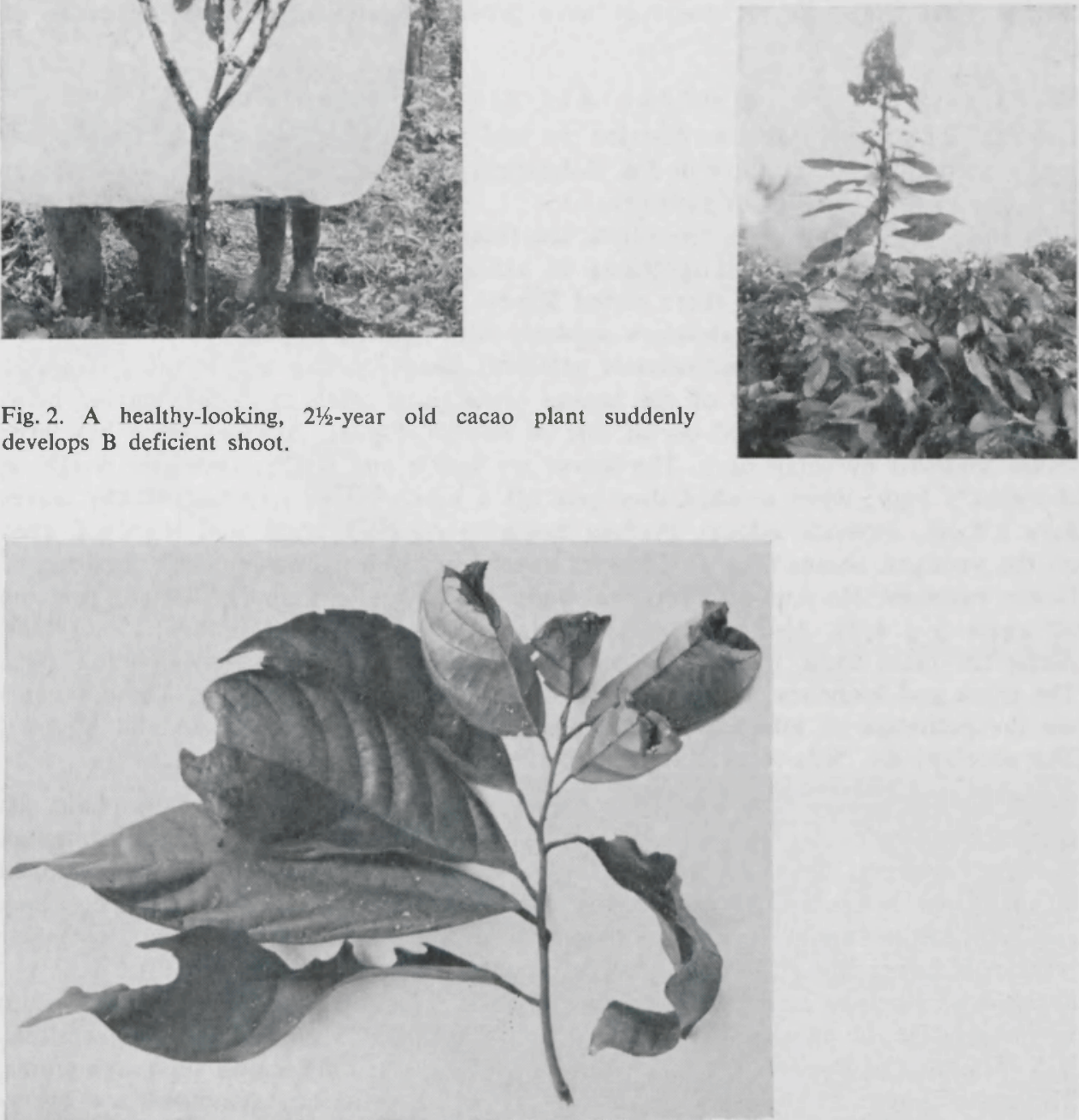

Fig. 3. Leaf symptoms of B-deficiency; curling and twisting. Four youngest leaves: small, pale, necrotic apical ends, necrotic midribs. Necrotic ends dropped out of three older leaves, shrivelled growing point. (Photo Dr. L. M. Hutchins) 
Furthermore, the very common leaf-deficiency symptoms in these plantations coincided with the B-deficiency symptoms artificially induced by LouÉ (1961) in pot experiments undertaken for the purpose of studying mineral deficiencies in cacao.

Unknown to the present author at that time, FreDriksSON (1962, p. 20) had predicted such sterility 18 months before in an earlier report submitted to Hda Clementina, Ecuador. His opinion was based on the low B-content found from soil analyses. He states that in the first place fruit-set will be hampered by boron deficiency.

Analyses of the subsoil of Hda Pate carried out in 1963 demonstrated the almost entire absence of water-soluble B (traces of up to 0.03 p.p.m.). Since the writer's first paper on the incidence of B-deficiency in cacao (TollenaAr, 1964) was read at a meeting of the American Society for Horticultural Science held in Venezuela in September 1964 trials with $B$ dressings have proved B-deficiency to be the cause of the trouble.

\subsection{Description of boron-deficiency symptoms}

LOUÉ (1961) was only able to describe the leaf symptoms of pot plants. The following is a complete description of the B-deficiency symptoms during the development of cacao in the field, up to maturity.

First stage. Profuse chupon formation, too frequent "flushing" of the young plantations. Flower formation and sprouting of axillary buds on the youngest internodes (terminal shoots). Here and there curled leaves.

Second stage. A new shoot develops suddenly with marked, typical symptoms (Fig. 2). The last leaves are the most severely affected: heavy curling and twisting, necrotic brown leaf tissue at the tip of the lamina (dead parts often drop out, leaving holes in the lamina), and cankered dorsal side of midrib (Fig. 3). A shoot often has large leaves followed by small ones. The leaves are brittle and rough; their dry weight is abnormally high; when crushed they give off a musty odour (crushed healthy leaves have a fresh, aromatic odour). Profuse flowering on main trunk and branches, even on the youngest shoots (Fig. 4). Flowers appear in clusters and bunches. Swelling of flower cushions. No fruit-set. Terminal buds die and axillary shoots develop and die off again (Fig. 4, 5). Also very profuse chupon formation (Fig. 6) exhausts the plant. Along the main trunk it leads to vast swellings and often formation of knob galls. The trunk and branches crack and start to bleed, black-rot areas arise. These wounds are the pathways of infection by diseases (Ceratocystis, Phytophthora) and borers 1. The root-tips die. Side-roots develop and die off again.

Third and final stage. Parthenocarpic fruits are formed (Fig. 1, 4). Many plants die from exhaustion caused by too frequent flushing. Chupon and side-branch formation. Profuse flowering. Repeated leaf-shedding, and dying of roots. The others are killed by secondary causes as Ceratocystis and root diseases. Even types like SCA 6, which are WB-resistant under normal conditions (also when artificially infected) lose their resistance during this final stage and become covered with vegetative WB.

Sensitivity of cacao types to boron scarcity. SCA 6 and SCA 12 (Amazon cacao) were found to be most B-demanding. The imported ICS clones are also sensitive. ICS 95 is one of the few that manage to survive and it only shows slight symptoms. The same is true of the local population; typical B-deficiency symptoms are every-

1 Bussler (1964) in a study of B-defíciency symptoms in 49 plants describes the following frequent phenomenon: "... reiszt die Rinde in mehr oder tiefen Spalten auf, die bis in das Mark der Pflanze durchgehen können. In diesen Stellen ist die Pflanze besonders empfänglich für Schädlingsbefall." 
Fig. 4. Youngest internode with flowers and lateral shoots. Defoliation, remaining leaves pale. Parthenocarpic fruit.

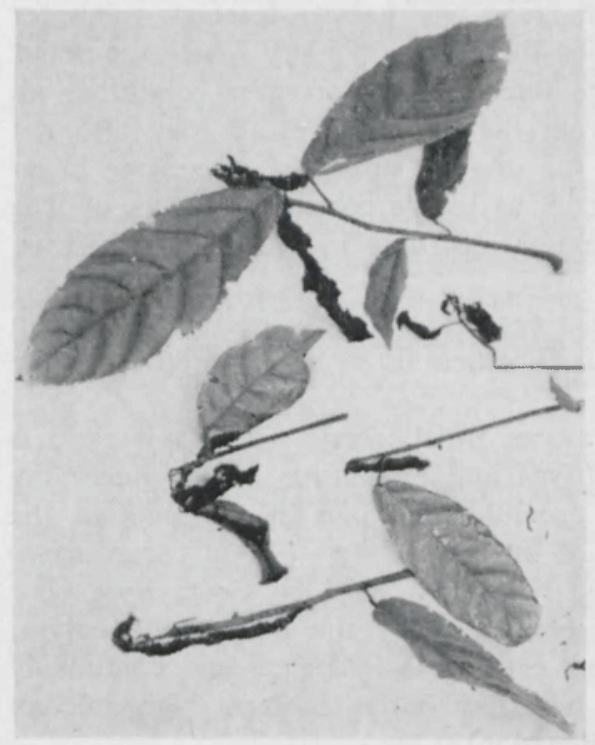

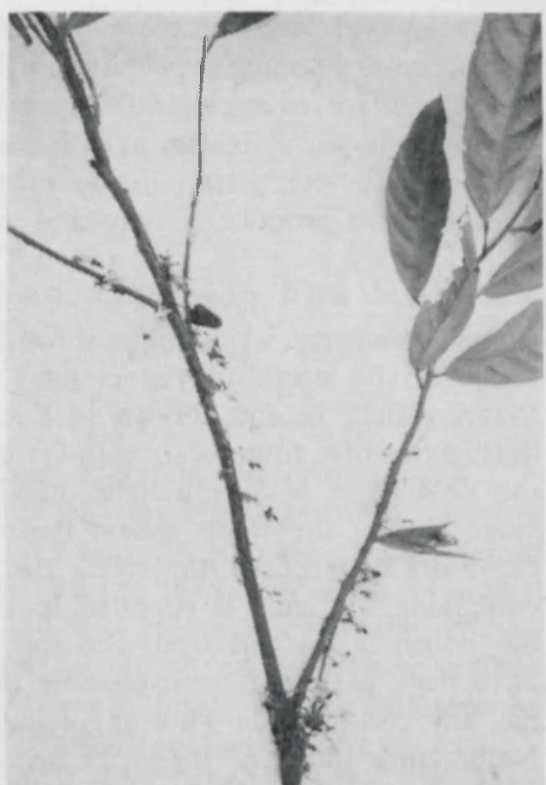

Fig. 5. B-deficiency: young shoots with pale leaves and shrivelled growing points.
Fig. 6. B-deficiency: profuse sprouting of chupons.

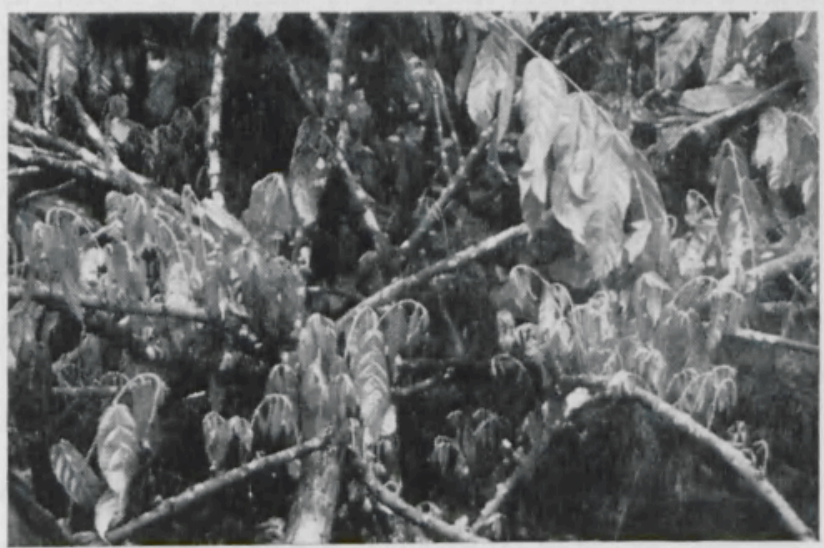


where in evidence, but these plantations, resulting from passive natural selection of non-boron-demanding types are not killed. But the low production of this population (compared, for example, with the cacao production of Bahia, Brazil) and its extreme sensitivity to such diseases as WB and Ceratocystis must be due to latent B-deficiency. Local populations grown in the province of $\mathrm{El}$ Oro on marine alluvium with plenty of soil boron produce heavily and are entirely free from B-deficiency symptoms.

\subsection{Soil and climatic conditions}

Boron deficiency is common throughout the main cacao belt of Ecuador, from the south to the north of the country in a zone designated by HARDY (1960) as the Riverine Belt. Its soil consists of thick layers of loose volcanic ashes. Heavy rains fall during the first four to six months of the year $(1,500-3,500 \mathrm{~mm})$; during the rest of the year there is only a light drizzle; atmospheric humidity is high throughout the year. During the rainy season these loose soil layers are heavily leached, rainwater flows off underneath (the rivers rise in the subsoil). During the dry season no water containing nutrients is supplied in the opposite direction. Under these conditions all the boron is leached from the soil, except from the humus layer (B may also not have been present in considerable amount in the original minerals). The zone never has any considerable wind supplying $B$ with rain, as in the coastal provinces of The Netherlands ( $80 \mathrm{~g}$ of $\mathrm{B}_{2} \mathrm{O}_{5}$ per hectare per annum according to HENKENS and LEHR, 1959).

The drought during the second half of the year aggravates B-deficiency. It is known from other parts of the world that the critical B-content is at a higher level during dry periods.

The high $\mathrm{Ca}$ content of these soils also aggravates $\mathrm{B}$-deficiency. The $\mathrm{Ca} / \mathrm{B}$ ratio is considered to be vital (Drake et al., 1941; Jones and Scarseth, 1944). According to HARDY (1960) the content of calcium is exceptionally high in the soils of the Riverine Belt; as a consequence he finds that of the $\mathrm{Ca}+\mathrm{Mg}+\mathrm{K}$ in cacao leaves $50-60 \%$ is in the form of calcium, compared with only $20 \%$ in Costa Rica. The very high exchangeable calcium content was confirmed by the many soil analyses which were carried out. The three main factors causing B-deficiency and continually emphasized in the literature (BERGER, 1949), viz. low boron content, high calcium content and drought, prevail in this zone of Ecuador.

A comparison was made between the boron content 1 of these soils, that of the marine alluvium near the coast at Machala ( $\mathrm{El}$ Oro), where no B-deficiency symptoms were noted, and that of the river levée ("La Isla") near the Pichilingue Experiment Station, where the symptoms were slight (Table 1).

The relationship between B-deficiency and the water-soluble boron content of the subsoil is obvious. The critical $\mathbf{B}$ content in Europe is in the region of 0.30 p.p.m. for dicotyledons, although it varies with the type of crop. Here the B content of the subsoil is only $10 \%$ of this critical limit. It is clear that the real trouble starts when the plants grow larger and at the same time become more dependent on the root system that has extended to the subsoil. When the plants are small and make limited demands, their roots mainly growing in the humus top-soil, the B-supply is sufficient.

A useful way of tracing the trouble spots is to determine the water-soluble B content.

1 All chemical analyses were carried out by the Soils Division of the Royal Tropical Institute, Amsterdam. 
Table 1. Water-soluble boron content of certain Ecuadorian soils

\begin{tabular}{|c|c|c|c|c|}
\hline \multirow[t]{2}{*}{ Location } & \multirow{2}{*}{$\begin{array}{c}B \text {-deficiency } \\
\text { symptoms }\end{array}$} & \multicolumn{2}{|c|}{ Water-soluble $B$ in p.p.m. } & \multirow{2}{*}{$\begin{array}{l}\text { Ca/B ratio } \\
\text { in leaves }\end{array}$} \\
\hline & & $\begin{array}{c}0-20 \mathrm{~cm} \\
\text { deep }\end{array}$ & $\begin{array}{c}0-80 \mathrm{~cm} \\
\text { deep }\end{array}$ & \\
\hline Hda Pate, A & very severe & 0.23 & 0.03 & 640 \\
\hline Hda Pate, B & very severe & 0.32 & 0.03 & 600 \\
\hline Hda Pate, C & very severe & 0.18 & trace & 735 \\
\hline Pichilingue .. & slight & 0.35 & 0.17 & 652 \\
\hline Machala $\ldots \ldots \ldots \ldots \ldots$ & none & 1.11 & 0.26 & 431 \\
\hline
\end{tabular}

In the case of this Scavina hybrid cacao 0.20 p.p.m. might be the critical limit. The figures obtained by FREDRIKSSON (1962) should also be mentioned. Soil analyses were carried out at depths of $0-10 \mathrm{~cm}, 10-20 \mathrm{~cm}$ and $20-30 \mathrm{~cm}$ at 22 different locations of $\mathrm{Hda}$ Clementina. Of the samples $23 \%$ had less than 0.20 p.p.m. of watersoluble $B$ in the $10 \mathrm{~cm}$ upper layer of the soil, in the next $10 \mathrm{~cm} 27 \%$ of the samples were below this limit, and $50 \%$ between 20 and $30 \mathrm{~cm}$. Even at such a shallow depth half of the samples were below the critical boron limit. It will therefore be no surprise that Scavina hybrid cacao at $\mathrm{Hda}$ Clementina became severely affected.

Leaf samples were sometimes analysed for additional information. In this case they did not help in the detection of B-deficiency. HAarer (1962) states that leaf analyses undertaken for the purpose of tracing B-deficiency in coffee are unreliable. But these analyses are really unnecessary because decisive evidence is provided by the watersoluble content of the subsoil.

Conclusions. Boron deficiency in these soils is a serious, widespread and persistent problem permitting no early solution as it will continually recur under the prevailing conditions because $(I)$ the B-content of the soils is low, (2) they are heavily leached during the rainy season, (3) no $B$ is supplied from the sea through rainfall, (4) the deficiency is aggravated by the high exchangeable calcium content and by (5) the prolonged periods of drought.

\subsection{Experime n t a l}

Experiment 1. The results of a few preliminary leaf spraying trials with $\mathrm{Cu}, \mathrm{Cu}+$ $\mathrm{Mn}+\mathrm{Zn}$ and B (in triplicate) were discussed in TollenaAR (1964). Only B gave a positive response: there was some increase in fruit-set in all three cases.

Experiment 2. The leaf canopy was sprayed with a $10 \%$ Solubor ${ }^{1}$ solution. Only two hours after spraying, the leaves of the youngest flushes showed a darkening of the green colour along the midrib and veins; the leaves also swelled. The trials repeated several times, always gave the same results.

Experiment 3. In March 196421 6-year old SCA 6 plants suffering from severe B-deficiency were fertilized at Hda Pate with $250 \mathrm{~g}$ per plant of a new type of B fertilizer ${ }^{2}$ called "Fritted Trace Elements" (F.T.E.) with $10 \%$ B. This artificial borosilicate is resistant to rain wash and according to MidDELBurg and VAN BAREN (1962) steadily releases its B. Six months later the new flush was normal and healthy, whereas the untreated plants produced the same diseased flush as before. This af-

1 Solubor manufactured by Borax Consolidated Ltd., London is especially developed for spraying purposes; it contains $20 \%$ of $\mathbf{B}$ in an easily soluble form.

2 F.T.E. is an artificial borosilicate glass manufactured by Ferro Enamels (Holland) Ltd., Rotterdam. 
Table 2. Comparison between new flush of fertilized (B frit) and untreated cacao

\begin{tabular}{|c|c|c|}
\hline & Untreated & Fertilized with $250 \mathrm{~g} \mathrm{~B}$ frit \\
\hline Leaf colour & pale & dark green \\
\hline Leaf texture & rough, brittle & flexible \\
\hline Leaf size.. & small, irregular & large, regular \\
\hline Leaf surface & curling & flat \\
\hline Average fresh leaf weight & $2.26 \mathrm{~g}$ & $3.80 \mathrm{~g}$ \\
\hline Dry weight in $\%$ of wet & $35.4^{\circ}$ & $31.6^{\circ}$ \\
\hline \multicolumn{3}{|l|}{ Odour of crushed } \\
\hline fresh leaf... & dead, musty & aromatic, spicy \\
\hline \multicolumn{3}{|l|}{ Plants flushing on } \\
\hline October 26,1964 & $78 \%$ & $40 \%$ \\
\hline November 13,1964 & $80 \%$ & $8 \%$ \\
\hline $\mathrm{Ca} / \mathrm{B}$ ratio in leaf & 360 & 298 \\
\hline
\end{tabular}

forded experimental proof that B-deficiency was at the root of the trouble (Table 2). The new flush of the fertilized plants was normal; the high dry weight typical of boron-deficient leaves (LouÉ, 1961) had disappeared. There was no further permanent flushing. The $\mathrm{Ca} / \mathrm{B}$ ratio of the leaves was again not very indicative.

The experiment'also showed that although the new flush is normal, the earlier developed trunk and branches with deformed tissues cannot be repaired. It was already too late to cure the whole plant. It was therefore important to carry out a trial with B applications applied to young plantations still free from abnormalities. At Hda Salgana a boron spraying trial was carried out in a still healthy $11 / 2-2$-year old Trinitario-Scavina plantation. Hundreds of plants were sprayed with Solubor. Another part was sprayed a second time, the rest remained unsprayed. About 6 months later considerable differences became apparent. The untreated area was severely affected and had already reached stage 2 ; the twice-treated plants were of healthy appearance and the once-sprayed plants showed slight symptoms of B-deficiency.

Experiment 4. Cacao seedlings have a taproot which penetrates into the subsoil where it develops an extensive root system. Rooted cuttings have no taproot and only develop a horizontal root system in the topsoil, which is why they often fall over as they grow larger. In the same Hda Pate block a comparison was made between seedlings of Trinitario-Scavina hybrids and rooted cutting of the same families. After 5 years most seedlings had died, but most rooted cuttings had grown into large plants, although showing some B-deficiency symptoms and yielding little fruit. The fact that the seedlings collapsed indicates that it is the low B content of the subsoil that is at the root of the trouble. This is also of practical importance.

Experiment 5. EATON and BLAIR (1935) reciprocally grafted plants having varying capacities of absorbing $B$ from the soil and found that the rootstock determined the B content of the leaves of the scion. ICS 95, a clone which shows few symptoms of B deficiency, was grafted at Hda Clementina on Trinitario-Scavina hybrids as rootstock. In hundreds of replications the first ICS 95 shoot that developed showed very severe B-deficiency symptoms. This might also be of practical importance since it might be possible to use the rootstock of types that readily extract $B$ from the soil. Experiment 6. An ICS fertilizer experiment at Hda Clementina with NP, NK, PK, NPK and a control, four replications and annual applications of fertilizer, had given unexplicable results. During the first years the plants showed a positive response to the fertilizers, but when they were five years old cacao production dropped with $\mathbf{N}$ 
Table 3. Fertilizer experiment with ICS 1. Effect of N, P and K

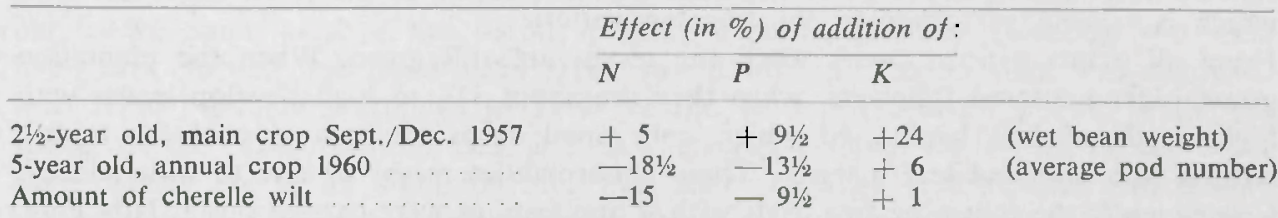

and $\mathrm{P}$ and the experiment was terminated.

The striking difference in fertilizer response between a very young plantation and a fully grown one can now be explained by the B condition of the plants. When fully grown the plants had become sensitive to B-deficiency, a condition which, as is wellknown, is aggravated by $\mathbf{N}$ and $\mathbf{P}$. In the later years the ICS 1 plants developed leaf symptoms which are now recognised as B-deficiency. FrEDRIKSSON (1962) noticed the very low B content of leaves sampled from the different plots of this experiment (untreated 21.2; PK 15.2; N only 10.5 p.p.m. B) and concluded that B trials had become necessary. The amount of cherelle wilt is an index of production (TollenaAR, 1959). It confirms the drop in productivity with $N$ and $P$.

Conclusion. Unless the boron problem in these soils is solved, most of the time and money spent on fertilizing, introducing high-yielding types and disease control will be wasted.

\section{Bananas}

Bananas are a very important crop on these Riverine Belt soils. They have a fairly shallow root-system, and being monocotyledons their B requirements are limited. Yet signs of the first stage of B-deficiency may be present. Peculiar leaf abnormalities (Fig. 7) are very common in this zone and they are unknown on the marine alluvium. Part of the leaf-tips break, another part of the leaf ends are torn to pieces (without the influence of any wind) and these ends turn brown. Especially the leaves that appear during the last 4 months before flower-shooting are affected in his way. The brown colour of these dead leaf ends and margins resembles leaf-tip burning caused by Sigatoka leaf-tip infection but it has nothing to do with it. It gives the plantations in this zone with its dead brown leaf tips an unhealthy appearance, especially

Fig. 7. Gros Michel at Hda Pate, Ecuador. "Hooking" and damaged leaf tips are visible against the clear sky.

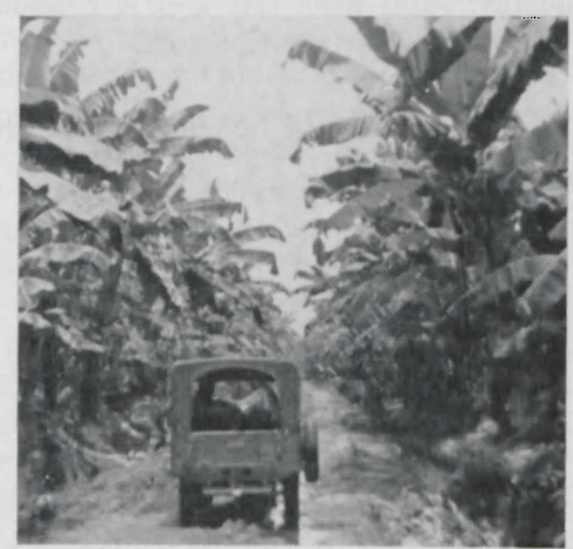


when seen from the air. Besides that many lamina are undulating or slightly twisting, which is especially marked in the Lacatan variety.

From all plants petioles break when the leaves are still green. When the plantation grows older scattered followers, when they are about $11 / 2 \mathrm{~m}$ high develop leaves with highly reduced leaf lamina, of which only small strips on both side of the midrib remain with crenated leaf margins. These abnormalities might be due to B-deficiency. Consequently the following two trials with B applications were carried out at Hda Pate. Experiment 1. In November 1964 a plot of 8-month old Gros Michel bananas were given $25 \mathrm{~g}$ of Solubor and another plot got $50 \mathrm{~g}$ per mat, worked under the soil around the mats (there were 900 mats to the hectare). The number of "hooked", "torn but not hooked", and normally developed leaves was counted in March 1965. Only the two youngest leaves on each plant were recorded (Table 4).

The leaf abnormalities were reduced by the application of $\mathbf{B}$.

Table 4. The effect of Solubor on the leaves of Gros Michel bananas

\begin{tabular}{lccccc}
\hline & $\begin{array}{c}\text { Normal } \\
(\%)\end{array}$ & $\begin{array}{c}\text { Torn but not hooked } \\
(\%)\end{array}$ & $\begin{array}{c}\text { Hooked } \\
(\%)\end{array}$ & Number of observations \\
\hline Unfertilized $\ldots \ldots \ldots \ldots$ & 24 & $\ldots 1$ & 35 & 96 \\
25 g Solubor per mat $\ldots$ & 52 & 38 & 10 & 49 \\
50 g Solubor per mat $\ldots$ & 54 & 31 & 15 & 34 \\
\hline
\end{tabular}

Experiment 2. On November 11, 1964 a Solubor spraying trial was carried out from the air in cooperation with "Atomec". A 25-hectare block of 7-year old Gros Michel was atomized with 341 per hectare of water containing $8 \mathrm{~kg}$ of Solubor; 50 hectares of the same plantation were left unsprayed. At the end of each month the number of green leaves on grade 38 fruit-stems (diameter of fingers $=8 / 32^{\prime \prime}$ ) were recorded. Recording was started four months in advance of the treatment.

Foliar applications of $\mathbf{B}$ had an immediate effect on the number of green leaves; in time the effect gradually declined. In the same way the green leaf number was noted of plants that had just shot. The differences in leaf number were: before spraying $-0.55,-0.20$; after spraying $+0.90,+0.50,+0.45,+0.55$ and +0.05 . These first trials indicate that the banana leaf canopy in the Riverine Belt is suffering from B-deficiency. It reduces the number of green leaves and impairs the fruit quality. Fruit from this area is considered poor owing to the abundance of "crema", "green-ripes" or pre-ripening.

Table 5. Effect of Solubor on the green-leaf number of fruit-bearing bananas

\begin{tabular}{|c|c|c|c|}
\hline Before spraying & $\begin{array}{c}\text { Untreated } \\
I\end{array}$ & $\begin{array}{c}\text { Solubor } \\
\text { II }\end{array}$ & $\begin{array}{c}\text { Differences } \\
I I-I\end{array}$ \\
\hline End of July + end of August, $1964 \ldots \ldots$ & 9.50 & 9.30 & -0.20 \\
\hline End of September + end of October $\ldots \ldots$ & 10.00 & 9.85 & -0.15 \\
\hline $\begin{array}{l}\text { After spraying (on November 11, 1964) } \\
\text { End of November }+ \text { end of December } \ldots \\
\text { End of January }+ \text { end of February, } 1965 \ldots \\
\text { End of March }+ \text { end of April } \ldots \ldots \ldots \ldots \ldots \\
\text { End of May }+ \text { end of June } \ldots \ldots \ldots \ldots \ldots \\
\text { End of July }+ \text { end of August } \ldots \ldots \ldots \ldots\end{array}$ & $\begin{array}{l}9.75 \\
9.70 \\
9.65 \\
9.55 \\
9.95\end{array}$ & $\begin{array}{l}10.55 \\
10.30 \\
10.25 \\
10.05 \\
10.20\end{array}$ & $\begin{array}{l}+0.80 \\
+0.60 \\
+0.60 \\
+0.50 \\
+0.25\end{array}$ \\
\hline
\end{tabular}


Some fertilizer trials are of interest in this connection. A 16-8-16 trial was carried out in the same area as the boron spraying experiment. The plantation was then five years old and had never been given any fertilizers. The response was negative; with NPK production dropped to $84 \%$ of the untreated control, similar to the response of the cacao fertilizer trial at Hda Clementina. Other trials with $\mathrm{N}$ and NPK were carried out in an adjoining area and their effect on leaf number and quality studied. In all cases both dropped (fewer leaves, more "crema"), particularly $\mathbf{N}$ had a depressing effect (Examples of green-leaf number at harvesting: untreated 7.3, urea 6.2, NPK 6.5; untreated 6.9, urea 5.7, NPK 6.2).

\section{Boron deficiency observed in other tropical crops in Ecuador}

Do other crops of which the B-deficiency symptoms are known, show those abnormalities on the Riverine Belt soils?

Arabica coffee. B-deficiency is well-known from Africa (HAARER, 1962; also see $A n$ Atlas of Coffee Pests and Diseases, published by the Coffee Board of Nairobi ; Culot and van Wambeke, 1958), Central America (Muller, 1958) and Brazil. The authors' colour plates and description show the characteristics common to all boron-deficient plants, viz. curled leaves, dead growing points, fan-like multiple branching; the occasionally deformed, elongated leaves turn pale, the leaves often have olive-green margins and are shed early; some of the berries shrivel. Typical B-deficiency was found throughout the area. In the opinion of A. Marchand (Kivu Province, Congo, a notorious B deficient area) B-deficiency in coffee is severe in this area of Ecuador. He doubted whether it could be cured by spraying only; soil applications might be necessary. The same was observed as in cacao, viz. all is well until the coffee plants enter the reproductive stage.

Robusta coffee. At certain periods the Rockefeller farm "Cafe Robusta" had a healthy leaf canopy, but at the end of the dry season (November 1964 and 1965) a heavy B deficient flush suddenly appeared on the C. robusta plants with all its typical characteristics.

Avocado pear. Typical B deficient Avocado plants were found throughout the zone, similar to those illustrated in JACOB and VON UExKülL (1958).

Chinese cabbage (Brassica pekinensis). A planting from imported seed completely collapsed from B-deficiency (heart rot) before reaching maturity.

Mango. Fine mangos are grown on the marine alluvium of the Guayas delta and produce abundant normal size fruit. On the other hand, on the volcanic terraces of the Riverine Belt mango trees often have elongated, curling, pale leaves with dead tips on a "rosette" branch system. Very poor mango fruit of the size of walnuts and with black necrotic spots is sold on the markets of Empalme and Quevedo. The leaf symptoms resemble those known from other B-deficient plants and the fruit necrosis tallies with what was found in India (DAS-GuPTA and SEN, 1960) to be $\mathrm{B}$-deficiency in mango.

This concludes the survey of tropical crops of which B-deficiency symptoms are known from literature. But there are other crops in this area which have ailments of which the cause is unknown. Citrus for example, causes much trouble in this zone. Many groves die out completely. Groves are known which did not produce a single flower until they were 6 years old and then gradually died. There may be other causes, e.g., Phytophthora and lack of sunshine, but B-deficiency should in 


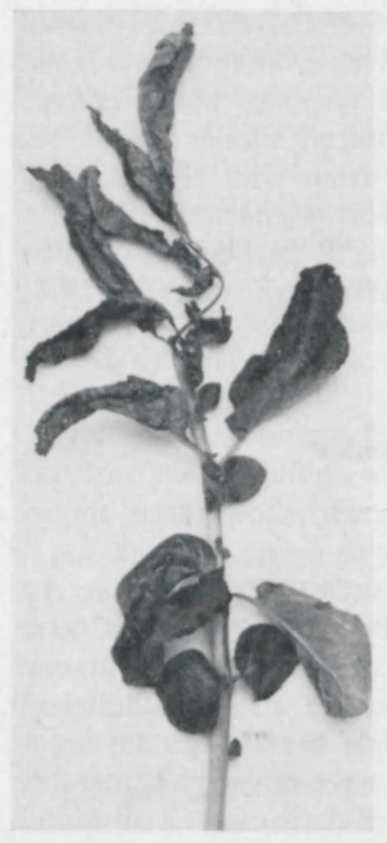

Fig. 8. Imported potato clone at the experimental farm "Sta Catalina", Quito, 1964. Severe B-deficiency: leaf curling, terminal leaves dead, reddish brown.

Fig. 9. Alfalfa at "Sta Catalina". B-deficiency: profuse branching, pale, shrivelling leaves with reddish leaf tips on side-shoots. No flowers.

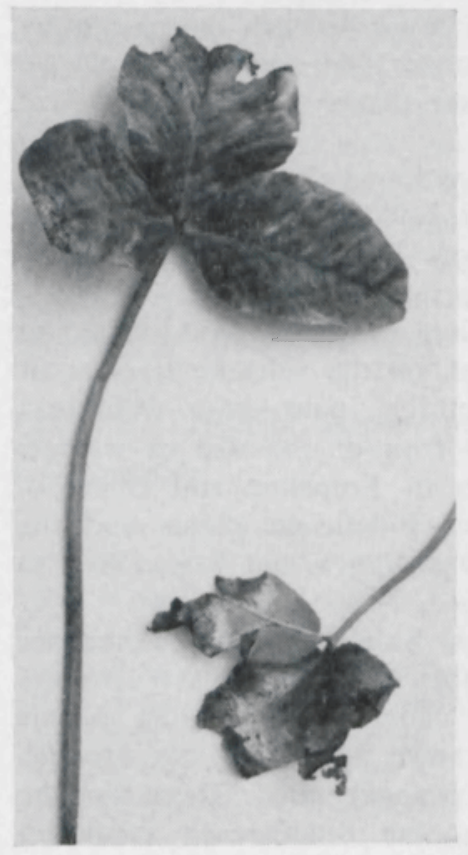

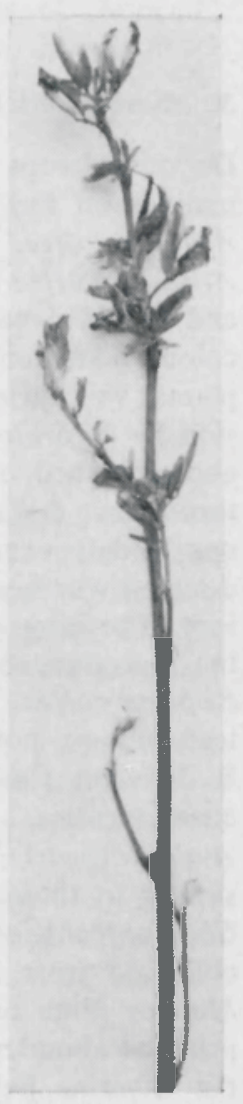

Fig. 10. Trifolium repens at "Sta Catalina". B-deficiency: curling leaves with dead, red and yellowish tips. 
certain cases also be borne in mind. A commercial tomato planting developed well until it started to flower, when for some unknown reason it died before the fruit could be harvested. Hundreds of papaya trees in a $\mathrm{B}$ deficient cacao area showed typical leaf curling and yellow-edged leaves. This might be B-deficiency, but there is no published evidence of the symptoms for papaya. A trial area of tea developed until a few years old, two years later it had shrivelled away and disappeared. No reason was known for this collapse, but today this resembles B-deficiency.

Chenery (1958) explained why B-deficiency had never been observed in tea plantations, although the typical symptoms were induced and growth disrupted in pot experiments. In all tea areas the soils are acid and contain a small amount of exchangeable calcium, but the Riverine Belt is rich in it.

\section{Boron deficiency in the temperate zone of the highlands}

Many temperate zone crops of which B-deficiency symptoms are familiar to agronomists, are grown in the highlands of Ecuador.

Except for apple trees, which showed the typical curling and die-back, no B-deficiency was observed in the often well managed Indian plantations of potatos, cabbage and beans.

According to the Director-General of the National Agricultural Research Institute (I.N.I.A.P.) at Quito, F. Portilla B-deficiency of alfalfa grown in the highlands had been known to him for seven years and it could be observed at the experimental farm "Santa Catalina", near Quito. This farm is situated at an altitude of $3.000 \mathrm{~m}$ on young volcanic soil of a beautiful texture. When these trial fields were visited in October 1964 the following was noted.

Potato. There were some 300 blocks of different potato clones. Most were indigenous, properly developed types, $1 \mathrm{~m}$ in height that flowered abundantly. Here and there an unsuccesful block could be observed, where the plants were creeping and stunted, without flowers, often plants were missing. A few blocks had died altogether. According to the potato expert G. Albornoz all these stunted varieties had been imported from Europe and the U.S.A. and their abnormal behaviour might be failure to adapt themselves to Andean conditions. In my opinion the imported varieties were not adapted to local conditions because they were suffering from severe B-deficiency, as shown by the crippled development, curled, pale leaves which had died at the end of the branches and then were reddish-brown in colour (Fig. 8), the poor flower formation, die-back of branches and defective tubers. As in cacao, the local varieties were a natural selection of non-boron-demanding types.

Alfalfa. The local types were barely affected, but the imported types were dying from lack of B: no flowers, reddening of the upper leaves, numerous shrivelling side-branches (Fig. 9).

Trifolium repens. Imported types started to grow vigorously, but about the time that they should have flowered the leaves turned reddish, with dead tips (Fig. 10) and the plants soon began to die. The cause was unknown at the station, but it was undoubtly typical B-deficiency as known from Europe.

Trefoil (Lotus spec.). Of the imported fodder crops trefoil was the most severely attacked by B-deficiency. They branched excessively, forming thick brooms without flowers. The leaves were pale with dead tips and partly shrivelled. The entire bush died at an early stage, when the leaves had a reddish-brown colour (Fig. 11).

Neth. J. Agric. Sci., Vol. 14 (1966) No. 2 (May) 


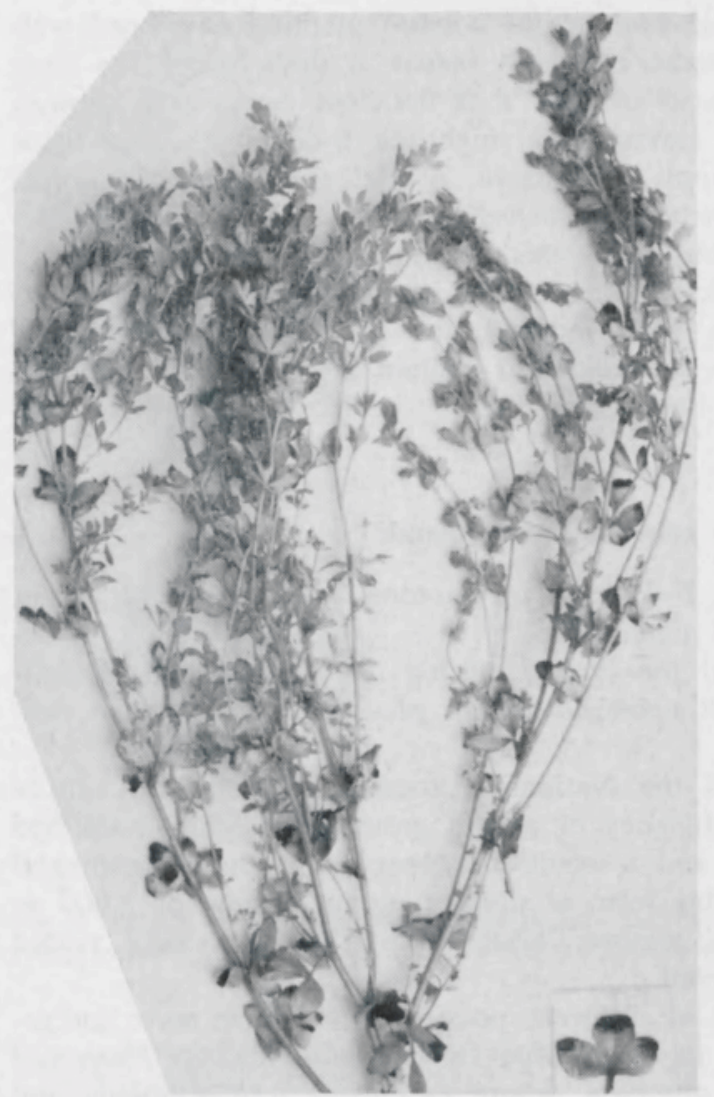

Fig. 11. Trefoil at "Sta Catalina". B-deficiency: broom-like branching, pale shrivelling leaves with red leaf tips. No flowers.

The findings in the lowlands are confirmed in the highlands, viz. that newly imported varieties of many crops are often not adapted to the very low B content of these young volcanic Andean soils. The first base should be selections from local populations. Newly imported types should be thoroughly tested with special reference to the B problem. It is remarkable that B-deficiency received little attention in Ecuador. Yet it seems to be of general occurrence, and as there are recent reports on B-deficiency in oilpalm plantations in Columbia (Bucaramanga) directly that they start to flower (I.R.H.O., 1964) and in grapevines and fruit trees in Chili, the problem may exist over wider areas of the volcanic Andes.

\section{RE F E R E N C ES}

Bartley, B. G. D.

BERGER, K. C.

BUSSLER, W.

Chenery, E. M.
1957 Trinitario-Scavina hybrids. New prospects for cocoa improvement. Repr. Cocoa Conf., 1957, London, pp. 36-40.

1949 Boron in soils and crops. Advan. Agron., 1, 321-351.

1964 Die Bormangelsymptome und ihre Entwicklung. Z. Pflanzenernährung, Dïngung, Bodenkunde, 105, 113-136.

1958 Boron deficiency in tea. Nature, 181, 426. 
Cope, F. W.

Culot, J. P. and WAMBEKE, A. Van

DAS-Gupta, S. N. and SEN, C.

Drake, D. M., StelLING, D. H. and Scarseth, G. D.

Eaton, F. M. and Blair, G. Y.

FREDRIKSSON, L.

HaARer, A. E.

HARDY, F.

Henkens, C. H. and LEHR, J. J.

I.R.H.O.

JACOB, H. and UEXKÜLL, $H$. von

JoNES, E. H. and Scarseth, G. D. Loué, A.

Middelburg, $H$. A. and BAREN, H. van Muller, L.

TollenaAR, D.

TollenaAR, D.
1958 Incompatibility in Theobroma cacao. A report on cocoa research 1957-1958, Trinidad, pp. 7-17.

1958 Contributions à l'étude des déficiences minérales du caféier d'Arabie au Kivu. Publ. I.N.E.A.C., Ser. Sci., 73, 105-111.

1960 Studies in the diseases of Mangifera indica. XI. The effect of boron on mango necrosis. Phytopathology, 50, 281-293.

1941 Calcium-boron as an important factor in controlling boron starvation. J. Am. Soc. Agron., 33, 454-462.

1935 Accumulation of boron in reciprocally grafted plants. Plant Physiol., 10, 411-424.

1962 Preliminär sammanställning av resultaten frän undersöckningar rörande växtnäringsförhällandend i marken pá Hda Clementina (unpublished).

1962 Modern Coffee Production. London, p. 495.

1960 Report on a visit to the Riverine Belt of Ecuador. Interam. Inst. Agr. Sci., Rept., 27, 103.

1959 Borium op bouwland. Landbouwvoorlichting, 16, 339-344.

1964 Journées d'études sur l'agronomie des oléagineux tropicaux. Oléagineux, 19, 297-331.

1958 Fertilizer Use, Nutrition and Manuring of Tropical Crops. Verlagsgesellschaft für Ackerbau mbH, Hannover, p. 491.

1944 The calcium-boron balance as related to boron needs. Soil Sci., 57, 15-24.

1961 Etudes des carences et des déficiences minérales sur le cacaoyer. Inst. Franç. Café Cacao, Bull., 1, 52.

1962 Bemesting met borium in fritvorm. Landbouwkundig Tijdschrift, 74, 865-871 (English summary).

1958 Recognition and control of minor element deficiencies in coffee. Turrialba, 8, 126-135.

1959 Increased cocoa production by foliar copper applications as an effect additional to witches' broom control. Trop. Agr., 36, 177-188.

1964 Boron deficiency as a cause of a disturbance in growth and production in cacao plantations of Ecuador. XIth Congr. Am. Soc. Hort. Sci., Caribbean Sect., 1964. 